Ф. В. Белкін, Р. В. Тарасов, В. А. Шкуропатенко, К. А. Прудивус, А. Г. Миронова, Л. М. Литвиненко

ННЦ «Харківський фізико-технічний інститут» НАН України, м. Харків, Україна

\section{Штучний фторапатит для іммобілізації золи від спалювання деревини Чорнобильської зони}

Уході досліджень синтезу аналога природного фторапатиту, основним компонентом якого є зола від спалювання твердих органічних відходів, зокрема від спалювання імітатора радіоактивної деревини Чорнобильської зони, отримано шихту, яку піддавали термообробці. Термічне розкладання шихти ісинтез фторапатиту досліджувалися методом термогравіметричного та диференціального термічного аналізу, фазовий склад золи після термообробок - методом рентгенівського фазового аналізу. Результати досліджень показують, що синтез кристалічного фторапатиту відбувається при порівняно низьких температурах $\left(600-700^{\circ} \mathrm{C}\right)$ за досить короткий проміжок часу.

Ключов і слова: радіаційні відходи, іммобілізація, зола, оксифосфат кальцію, фторапатит.

Ф. В. Белкин, Р. В. Тарасов, В. А. Шкуропатенко, Е. А. Прудывус, А. Г. Миронова, Л. М. Литвиненко

Искусственный фторапатит для иммобилизации золы от сжигания древесины Чернобыльской зоны

В ходе изучения синтеза аналога естественного фторапатита, основным компонентом которого служит зола от сжигания твердых органических отходов, в частности от сжигания имитатора радиоактивной древесины Чернобыльской зоны, получена шихта, которую подвергали термообработке. Термическое разложение шихты и синтез фторапатита исследовались методом термогравиметрического и дифференциального термического анализа, фазовый состав золы после термообработок - методом рентгенофазового анализа. Результаты исследований показывают, что синтез кристаллического фторапатита происходит при сравнительно низких температурах (600-700 ㄷ) за довольно короткий промежуток времени.

Ключевые слова: радиационные отходы, иммобилизация, зола, оксифосфат кальция, фторапатит.

(C) Ф. В. Белкін, Р. В. Тарасов, В.А.Шкуропатенко, К. А. Прудивус, А. Г. Миронова, Л. М. Литвиненко, 2012
$\Pi$ оводження з відпрацьованим ядерним паливом та радіоактивними відходами завжди знаходилося й знаходиться під пильною увагою вчених, фахівців та широкої громадськості $[1,2]$. Це стимулює розробку високоефективних методів, які забезпечують створення бар'єрних та іммобілізаційних матеріалів з високими експлуатаційними характеристиками, що, зокрема, мають високі корозійні та радіаційні властивості. Доступними та простими методами такі матеріали створити неможливо. Порівняно з традиційно застосовуваними матеріалами, отриманими методами бітумування, цементування й оскловування, перспективнішими є матеріали на основі кристалічних сполук. Найбільш придатні в цьому сенсі аналоги природних матеріалів, що містять у природному стані протягом тривалих періодів часу радіонукліди [1-3, 6-8]. До подібних аналогів належать такі природні мінерали, як цирконоліт, холондіт, перовскіт, циркон [1], шпінель [7], кордієрит [8] тощо. Одним з перспективних мінералів може бути фторапатит - $\mathrm{Ca}_{5}\left(\mathrm{PO}_{4}\right)_{3} \mathrm{~F}$ [6], оскільки його структура в природних умовах має високу хімічну й термічну стабільність. Фторапатит входить до складу природних гірських порід, які містять у природному стані радіоактивні речовини, іє відомим радіаційно-стійким матеріалом: пошкодження, викликані випромінюванням, нестабільні, і при температурі понад $60^{\circ} \mathrm{C}$ структура фторапатиту здатна відновлюватись [3]. Ця матриця також цікава тим, що в іiі структурі можуть бути численні заміщення. Зокрема, атоми кальцію можуть бути заміщені різними металами, в тому числі цезієм або стронцієм, які є головною загрозою в перші десятиріччя зберігання або захоронення радіоактивних відходів (РАВ).

Внаслідок Чорнобильської аварії на значній території України було припинено повноцінну господарську діяльність [4], зокрема сурові обмеження розповсюджуються на лісогосподарську. Це стосується значних лісових площ, що прилягають до зони відчуження. Одним з реабілітаційних заходів на цих територіях є іммобілізація золи від спалювання деревини, що забруднена радіонуклідами.

Метою даної роботи було дослідження синтезу аналогу природного фторапатиту з використанням як основного складового компонента золи від спалювання твердих органічних відходів, зокрема від спалювання імітатора радіоактивної деревини Чорнобильської зони.

\section{Методи дослідження та обладнання}

Для одержання фторапатиту $\mathrm{Ca}_{5}\left(\mathrm{PO}_{4}\right)_{3} \mathrm{~F}$ використовували золу - оксифосфат кальцію [5]. При розрахунку кількості компонентів для синтезу фторапатиту приймали, що зола є чистим оксифосфатом кальцію без будь-яких домішок. Для одержання фторапатиту вихідна шихта готувалася 3 таких компонентів: оксифосфат кальцію $\mathrm{Ca}_{4} \mathrm{O}\left(\mathrm{PO}_{4}\right)_{2}$, фторид кальцію $\mathrm{CaF}_{2}$, а також карбонат кальцію $\mathrm{CaCO}_{3}$ у вигляді крейди та ортофосфорна кислота $\mathrm{H}_{3} \mathrm{PO}_{4}$ для забезпечення стехіометричного складу фторапатиту. Після попереднього змішування компонентів отриману суміш сушили при температурі $30-40{ }^{\circ} \mathrm{C}$. Остаточне змішування й подрібнення висушеної шихти проводили в кульовому млині при співвідношенні маси шихти до маси куль 1:20. Термообробку здійснювали в печі МП-2У за таких умов:

1) при постійному часі витримки (70 хв.) в інтервалі температур $100-500{ }^{\circ} \mathrm{C}$ через кожні $100{ }^{\circ} \mathrm{C}$ та в інтервалі 550$800{ }^{\circ} \mathrm{C}$ через кожні $50{ }^{\circ} \mathrm{C}$;

2) при постійних температурах 600 та $700{ }^{\circ} \mathrm{C}$ впродовж $17-105$ хв. 
Термічне розкладання шихти і синтез фторапатиту досліджували методом термогравіметричного та диференціального термічного аналізу на деріватографі Q-1500 D в інтервалі температур $20-1000{ }^{\circ} \mathrm{C}$ при швидкості нагрівання $12{ }^{\circ} \mathrm{C} /$ хв. (маса зразка 1 г). Фазовий склад золи після термообробок досліджували методом рентгенівського фазового аналізу (РФА) на дифрактометрі ДРОН-1,5 (випромінювання $\mathrm{Cu} \mathrm{K} \mathrm{K}_{\alpha}$, Ni-фільтр).

\section{Результати експериментальних досліджень}

Дослідження впливу температури термообробки на повноту синтезу фторапатиту. Рентгенодифрактометричні дослідження вихідної суміші показали, що після змішування та сушіння шихту складають оксифосфат кальцію (безпосередньо зола), фторид кальцію, сліди карбонату кальцію. На рис. 1 видно, що лінія максимальної інтенсивності оксифосфату кальцію знаходиться на кутах $2 \theta=29 \ldots 30^{\circ}$, а фториду кальцію - на кутах $2 \theta=46 \ldots 47^{\circ}$.

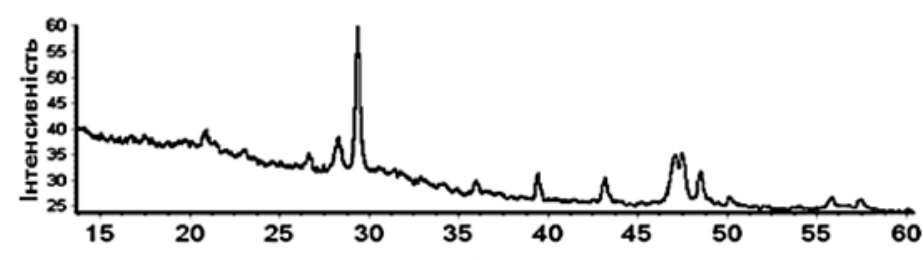

Рис. 1. Дифрактограма вихідної шихти

Результати термічного аналізу вихідної шихти представлено на рис. 2. На кривій диференціально-термічного аналізу виявлено присутність одного экзо- та двох ендотермічних ефектів. Могутній і слабкий розмитий ендотермічні ефекти виявляються в інтервалах температур 20-460

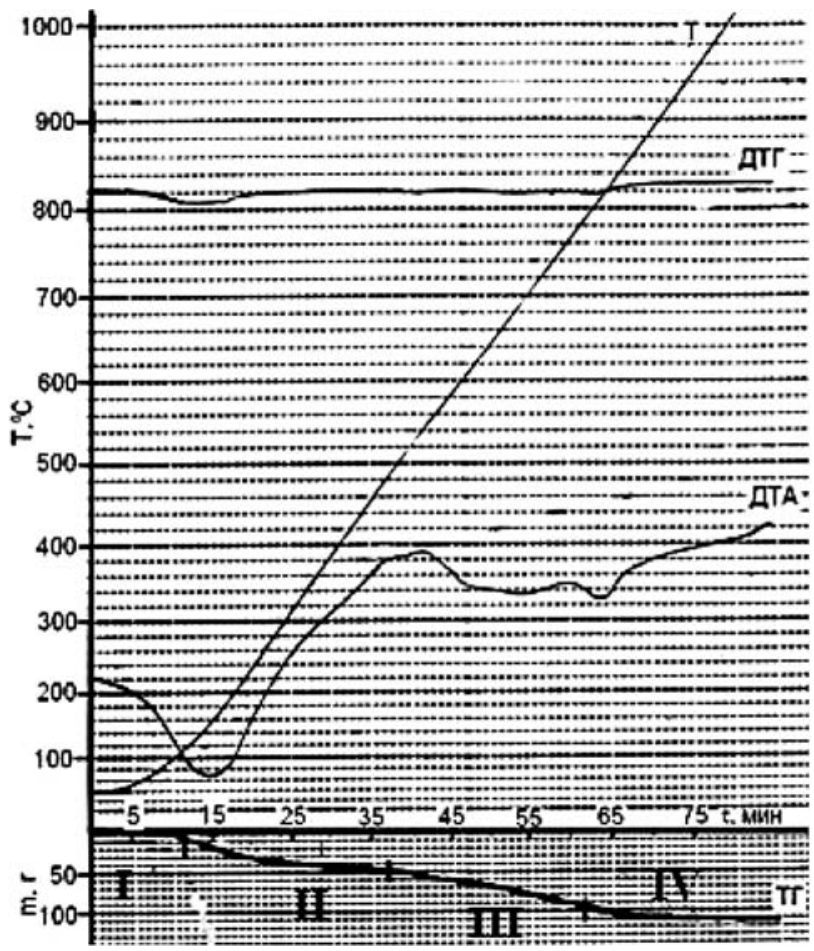

Рис. 2. Результати термогравіметричного

та диференціального термічного аналізу вихідної шихти та $760-880{ }^{\circ} \mathrm{C}$ з мінімумами при 160 та $820{ }^{\circ} \mathrm{C}$, відповідно. Трохи розмитий, середньої інтенсивності, екзотермічний ефект знаходиться в інтервалі температур $460-600{ }^{\circ} \mathrm{C}$ з максимумом при $540{ }^{\circ} \mathrm{C}$.

Синтез фторапатиту відбувається в чотири стадії, які відповідають точкам перегину на термогравіметричній кривій (ТГ) та екстремумам на кривій диференціальнотермічного аналізу (ДТА) і диференціальній термогравіметричній кривій (ДТГ). На першій стадії, в інтервалі температур 60-460 ${ }^{\circ} \mathrm{C}$, втрата маси становить 4,0\%, на другій (в інтервалі температур $460-600{ }^{\circ} \mathrm{C}$ ) $-2,5 \%$, на третій (в інтервалі температур $600-800{ }^{\circ} \mathrm{C}$ ) $-5,5 \%$. На четвертій стадіï, в інтервалі температур $800-1000{ }^{\circ} \mathrm{C}$, втрата маси практично відсутня. Втрата маси ілюструється не чітко означеними екстремумами на кривій ДТГ при температуpax 140 та $800{ }^{\circ} \mathrm{C}$. Загальна втрата маси становить $12 \%$.

Рентгенодифрактометричні дослідження показали, що термообробка шихти в інтервалі температур $100-400{ }^{\circ} \mathrm{C}$ не викликає змін фазового складу. Помітні фазові зміни починаються при температурі термобработки $500{ }^{\circ} \mathrm{C}$. На рис. 3 наведено дифрактограму зразка, який оброблено при $500{ }^{\circ} \mathrm{C}$ впродовж досить значного часу -70 хв. (для зручності порівняння на рис. 1 та 3 наведено, крім кутів, і відносні інтенсивності).

На дифрактограмі зразка, який термооброблено при температурі $550{ }^{\circ} \mathrm{C}$, з'являються вперше рентгенівські лінії фторапатиту. Проте, крім мінералу, що синтезується, спостерігаються рентгенівські лінії вихідних сполук.

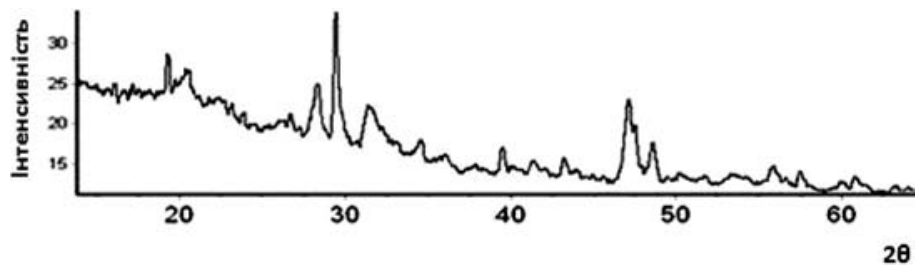

Рис. 3. Дифрактограма матеріалу термообробленого при $500{ }^{\circ} \mathrm{C}$ зразка

Подальші експерименти з термообробки при температурі $600{ }^{\circ} \mathrm{C}$ показали, що зростання інтенсивностей рентгенівських ліній фторапатиту припинилося. При цьому на дифрактограмі присутні лінії залишків фториду кальцію, який прореагував не повністю. Дифрактограми матеріалу зразків, які термооброблено при температурі 550 та $600{ }^{\circ} \mathrm{C}$, представлено на рис. 4 та 5.

Подальше підвищення температури термообробки викликає зростання зерен і приводить до більш упорядкованого стану кристалічної структури фторапатиту. Зміни фазового складу не відбувалися аж до температури термообробки $800{ }^{\circ} \mathrm{C}$. Крім фторапатиту, як і раніше, при температурі термообробки $800{ }^{\circ} \mathrm{C}$ на дифрактограмі матеріалу залишаються рентгенівські лінії фториду кальцію та слабкі рефлекси оксифосфату кальцію (золи).

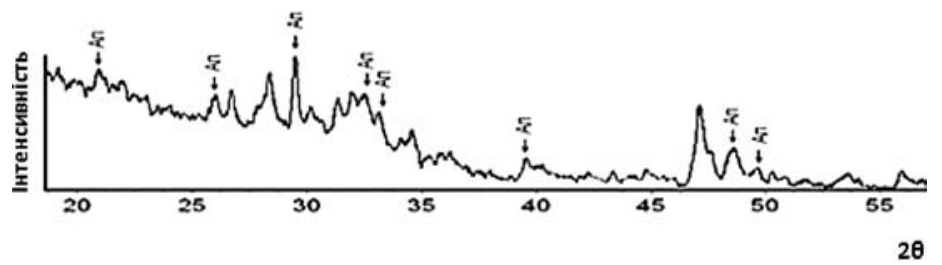

Рис. 4. Дифрактограма матеріалу термообробленого при $550{ }^{\circ} \mathrm{C}$ зразка (тут і далі Ап - лінії, що належать фторапатиту) 


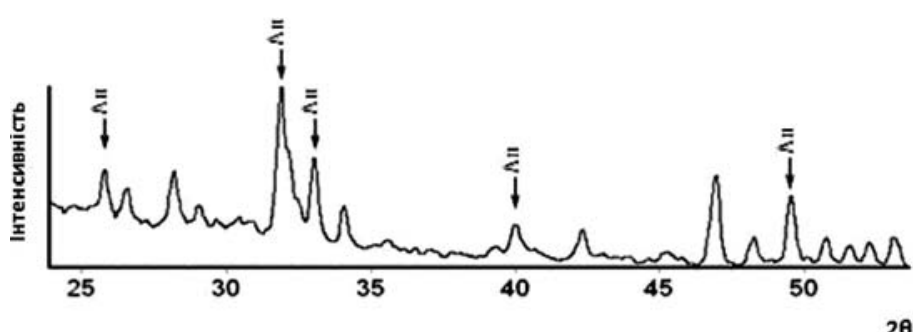

Рис. 5. Дифрактограма термообробленого при $600{ }^{\circ} \mathrm{C}$ матеріалу зразка

Дослідження впливу часу термообробки при постійній температурі на повноту синтезу фторапатиту. Термообробка шихти при $600{ }^{\circ} \mathrm{C}$ впродовж 17 хв призвела вперше до появи рентгенівських ліній фторапатиту, при цьому присутні також і вихідні фази. Слід зазначити, що найінтенсивніша лінія на дифрактограмі відповідає рентгенівській лінії з індексами (220), яка належить фториду кальцію (рис. 6, a).

Зростання інтенсивності рентгенівських ліній фторапатиту припинилося на дифрактограмі зразка, що пройшов термообробку протягом 70 хв. Подальше збільшення часу витримки сприяє більшому упорядкуванню структури фторапатиту. Остаточне упорядкування структури фторапатиту відзначається на дифрактограмі зразка, термообробленого при температурі $600{ }^{\circ} \mathrm{C}$ впродовж 105 хв (рис. 6, б).

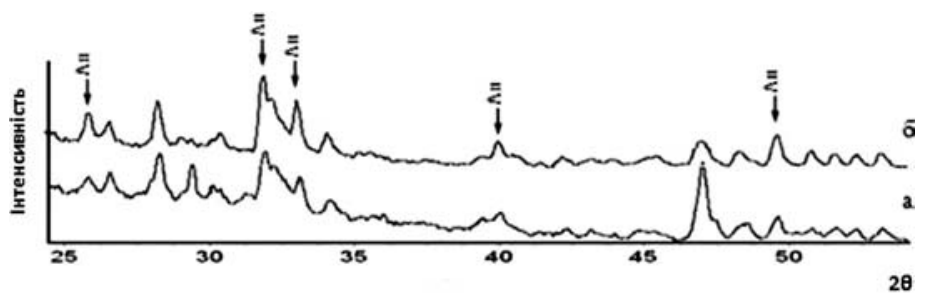

Рис. 6. Дифрактограма матеріалу термообробленого впродовж 17 хв (a) та 105 хв (б) при $600{ }^{\circ} \mathrm{C}$ зразка

Термообробка при температурі $700{ }^{\circ} \mathrm{C}$ зі збільшенням часу витримки так само приводить до зростання інтенсивності рентгенівських ліній фторапатиту, однак воно припиняється вже за 17 хв. Отримана структура фторапатиту є досить упорядкованою (рис. 7).

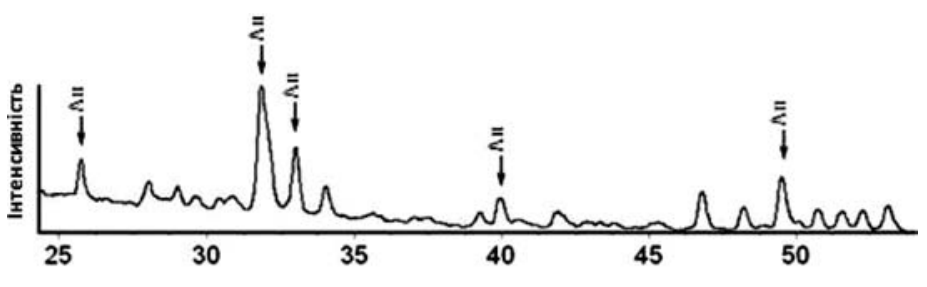

Рис. 7. Дифрактограма матеріалу термообробленого впродовж 17 хв. при $700{ }^{\circ} \mathrm{C}$ зразка

\section{Аналіз і обговорення результатів}

Кожна стадія на кривій ТГ характеризується притаманним їй процесом, який відбувається під час термічної обробки вихідної шихти фторапатиту. Порівняння резуль- татів термогравіметричного, диференціально-термічного і рентгенофазового аналізів показує, що в інтервалі температур 20-500 ${ }^{\circ} \mathrm{C}$ видаляється сорбована вода, про що свідчать втрата маси на кривій ТГ (рис. 2), ендотермічний ефект на кривій ДТА (рис. 2) і незмінність фазового складу шихти (рис. 1 та 3).

В інтервалі температур 550-700 ${ }^{\circ} \mathrm{C}$ проходить синтез фторапатиту. Про це свідчать дифрактограми термооброблених зразків (рис. 4-7). Температурі початку синтезу фторапатиту відповідає температура екстремуму екзотермічного ефекту $540{ }^{\circ} \mathrm{C}$ (рис. 2, крива ДТА) та дані рис. 4. Синтез фторапатиту завершується при температурі $600{ }^{\circ} \mathrm{C}$ і витримці у 70 хв, тобто синтез фторапатиту повністю відбувається в межах екзотермічного ефекту $\left(460-600{ }^{\circ} \mathrm{C}\right)$.

В інтервалі температур $700-850{ }^{\circ} \mathrm{C}$ спостерігається втрата маси, обумовлена розкладанням залишків карбонату кальцію [9, 10] та супроводжувана упорядкуванням структури фторапатиту, що підтверджується другим ендоефектом на кривій ДТА, втратою маси на кривій ТГ (рис. 2) і даними дифрактограм фторапатиту (рис. 6 та 7). Підвищення температури термообробки до $700{ }^{\circ} \mathrm{C}$ приводить до синтезу фторапатиту за менший час витримки (17 хв). Подальше зростання температури приводить до упорядкування кристалічної структури та свідчить про термічну стабільність фторапатиту при нагріванні в дослідженому інтервалі температур.

Вміст у фторапатиті однієї з вихідних фаз, такої як фторид кальцію, а також наявність слідів карбонату кальцію можна пояснити тим, що застосований фторид кальцію брали згідно з розрахунками по реакції утворення в незначній кількості, а частки порошку були в крупнозернистому стані, що не сприяло рівномірному розподілу його по об’єму шихти, тому в процесі синтезу в місцях його надлишку частина фториду не ввійшла до структури фторапатиту.

\section{Висновки}

Результати проведених досліджень свідчать про те, що для іммобілізації радіонуклідів, які знаходяться в золі деревини Чорнобильського району, за матрицю може бути використано штучно синтезований мінерал фторапатит, основним компонентом для синтезу якого $є$ оксифосфат кальцію, тобто безпосередньо зола. У даній роботі за допомогою термогравіметричного, диференціально-термічного та рентгенофазового аналізів показано, що синтез фторапатиту при додаванні в золу деревини фториду кальцію, карбонату кальцію та ортофосфорної кислоти проходить протягом 70 хв при температурі термообробки $600{ }^{\circ} \mathrm{C}$ i 17 хв при температурі $700{ }^{\circ} \mathrm{C}$. Збільшення часу витримки до 105 хв при температурі термообробки $600{ }^{\circ} \mathrm{C}$ сприяє упорядкуванню структури фторапатиту.

Однією з головних переваг синтезованого фторапатиту $€$ відносно низька температура його синтезу та використання як основного компоненту 70-75\% (ваг.) оксифосфату кальцію, тобто золи, яку отримано від спалювання імітатора деревини, забрудненої радіонуклідами.

Синтезований фторапатит можна рекомендувати як перспективний мінералоподібний матричний матеріал для іммобілізації радіонуклідів, зокрема тих, що містяться в золі деревини Чорнобильського району. 


\section{Список використаної літератури}

1. Ядерная энергетика. Обращение с отработавшим ядерным топливом и радиоактивными отходами: Обзор по материалам зарубежной и отечественной печати / В. М. Ажажа, В. А. Белоус, С. В. Габелков, Е. Д. Джур, Ю. А. Крикун, В. В. Левенец, Г. В. Лисиченко, И. М. Неклюдов, С. Ю. Саенко, Р. В. Тарасов, Б. А. Шиляев, Б. М. Широков, А. В. Шур; под ред. И. М. Неклюдова. - К.: Наук. думка, 2006. - 253 с.

2. Шпак А. П. Апатиты / А. П. Шпак, В. Л. Карбовский, В. В. Трачевский. - К.: Академпериодика, 2002. - 414 с.

3. Карпена Жоэль. Способ захоронения плутония в апатитовой керамике и продукт, полученный с использованием этого способа / Карпена Жоэль, Буае Лоран, Лаку Жан-Луи. - Федеральная служба по интеллектуальной собственности, патентам и товарным знакам. Российская Федерация, 1999.09.10, заявка № 2001110070/06.

4. Шитюк К. Ф. Особливості перерозподілу ${ }^{90} \mathrm{Sr}$ та ${ }^{137} \mathrm{Cs}$ в системі «грунт - сосна звичайна» лісових біогеоценозів зони ЧАЕС / К. Ф. Шитюк, В. О. Кашпаров, В. П. Процак // Зб. наук. праць Їнту ядерних досліджень. Радіоекологія та радіобіологія. - 2005. № 3 (16). - С. 122-130.

5. Цезийсодержащие фазы в древесных золах Чернобыльской зоны / Ф. В. Белкин, С. В. Габелков, Р. В. Тарасов, Н. С. Полтавцев, Л. М. Литвиненко, Т. П. Рыжова // Проблеми безпеки атомних станцій і Чорнобиля. - 2008. - Вип. 11. - С. 136-141.

6. Синтез аналога природного фторапатита для иммобилизации древесной золы Чернобыльской зоны / Ф. В. Белкин, С. В. Габелков, Р. В. Тарасов, Н. С. Полтавцев, Е. Г Ледовская Л. М. Литвиненко, Л. А. Пироженко // Тезисы доклада на XVIII Междунар. конф. по физике радиац. явлений и радиац. материаловедению, 8-13 сентября, 2008, г. Алушта, Крым. - С. 326, 327.
7. Магний-алюминиевой шпинель - инертная матрица для изоляции высокоактивных отходов / С. В. Габелков, Р. В. Тарасов, Н. С. Полтавцев, М. П. Старолат, Е. П. Березняк, А. В. Пилипенко, А. Г. Миронова, В. В. Макаренко // Тезисы доклада на XVIII Междунар. конф. по физике радиац. явлений и радиац. материаловедению, 8-13 сентября, 2008, г. Алушта, Крым. - С. 328, 329.

8. Синтез кордиерита - минералоподобного материала для изоляции РАО / Е. Г. Ледовская, С. В. Габелков, Р. В. Тарасов, Н. С. Полтавцев, А. В. Пилипенко, Ф. В. Белкин // Тезисы доклада на XVIII Междунар. конф. по физике радиац. явлений и радиац. материаловедению, 8-13 сентября, 2008, г. Алушта, Крым. C. 349,350 .

9. Карякин Ю. В. Чистые химические вещества / Ю. В. Карякин, И. И. Ангелов. - М.: Изд-во «Химия», 1974.

10. Справочник химика. - Т. 2: Основные свойства неорганических и органических соединений. - М.: Гос. науч.-техн. изд-во хим. лит-ы, 1963. 